\title{
Effect of feeding with safflower (Carthamus tinctorius L.) seed added mixed feed on the amount of fatty acids composition and cholesterol in chicken meat
}

\section{Aspir (Carthamus tinctorius L.) tohumu katkılı karma yemle beslemenin piliç etinde yăg asitleri kompozisyonu ve kolesterol miktarına etkisi}

\author{
${\text { Yasin } \text { YAKAR }^{1^{*}} \text { iD, Yener TEKELi }}^{2}$ iD \\ ${ }^{1}$ Harran University, Faculty of Engineering, Department of Food Engineering, Şanlıurfa, Turkey \\ ${ }^{2}$ Adıyaman University, Faculty of Pharmacy, Adıyaman, Turkey
}

\section{To cite this article:}

Yakar, Y. \& Tekeli, Y. (2019). Effect of feeding with safflower (Carthamus tinctorius L.) seed added mixed feed on the amount of fatty acids composition and cholesterol in chicken meat. Harran Tarım ve Gıda Bilimleri Dergisi, 23(1): 69-77. DOI: $10.29050 /$ harranziraat.449027

Address for Correspondence: Yasin YAKAR

e-mail:

yasinyakar@harran.edu.tr

Received Date:

30.07.2018

Accepted Date:

12.10.2018

() Copyright 2018 by Harran University Faculty of Agriculture. Available on-line at
www.dergipark.gov.tr/harranziraat

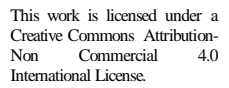

\section{ABSTRACT}

The effect of feeding with grinded safflower seed (GSS) added mixed feed on the amounts of fatty acids composition and cholesterol in chicken meat has been examined in this study. One-day-old broiler chicks have been used in trial. Four groups were formed each of which consisting of 30 chicks, 120 chicks in total. 4 different rations were prepared by adding $0 \%$, $2.5 \%, 5 \%$ and $10 \%$ grinded safflower seeds and were given to groups. Ad libitum feeding for 6 weeks for the broiler chick group was applied. In the group which was fed with $10 \%$ mixed feed including GSS, the cholesterol values in chicken meat was significantly lower $(P<0.05)$; and the polyunsaturated fatty acid (PUFA) values was higher compared the control $(P<0.05)$. In conclusion, GSS addition to broiler diet decreased amount of cholesterol and MUFA (monounsaturated fatty acid) and increased amount of PUFA.

Key Words: Safflower seed, Broiler chicken, Fatty acids composition, Cholesterol

Öz

Bu tez çalışmasında, öğütülmüş aspir tohumu (GSS) katkılı karma yemle beslemenin piliç etinde yağ asitleri kompozisyonu ve kolesterol miktarına etkisi araştırılmıştır. Denemede, 1 günlük yaştaki etlik civcivler kullanılmıştır. Her bir grupta 30 adet olmak üzere toplam 120 adet etlik civciv kullanılarak 4 grup oluşturulmuştur. Çalışmada, \%0 (kontrol), \%2.5, \%5 ve \%10 düzeylerinde öğütülmüş aspir tohumu katılmak suretiyle 4 farklı rasyon hazırlanmış ve gruplara verilmiştir. Etlik piliçlere 6 hafta süreyle ad libitum besleme uygulanmıştır. \%10 öğütülmüş aspir tohumu (GSS) içeren karma yemle beslenen grupta kontrol grubuna kıyasla, piliç etinde kolesterol değerinin önemli oranda düşük $(P<0.05)$, çoklu doymamış yağ asitleri (PUFA) miktarının ise yüksek $(P<0.05)$ olduğu tespit edilmiştir. Sonuç olarak, GSS'nun etlik piliç diyetine eklenmesi kolesterol ve tekli doymamış yağ asitleri (MUFA) miktarını düşürmüş, PUFA miktarını ise arttırmıştır.

Anahtar Kelimeler: Aspir tohumu, Etlik piliç, Yağ asitleri kompozisyonu, Kolesterol

\section{Introduction}

Safflower is a very branched, herbaceous and annual plant of the Asteraceae family. The plants reach a height of $150 \mathrm{~cm}$ with globular flower heads having cream, yellow, orange or red flowers (Dajue and Mündel, 1996). It is grown for oil, meal, birdseed, and raw material for various industrial products. Generally, the main use of safflower is for edible oil, some is used for 
birdseed, a small amount goes for industrial uses and the meal or whole seed is fed to dairy cattle. Medicinal uses of safflower have been important in countries such as China and India (Mündel et al., 2004).

There are two types of safflower varieties, one that is rich in PUFA (especially linoleic acid) and other that is high in MUFA (especially oleic acid). The oil in linoleic safflower contains about $70-80 \%$ linoleic acid and is used for edible oil products such as salad oils and soft margarine. Researchers disagree on whether oils high in polyunsaturated acids, help decrease blood cholesterol and the related heart and circulatory problems (Oelke et al., 1992).

The meal that remains after oil extraction is used as a protein supplement for livestock. The meal usually contains $22-25 \%$ protein and much fiber (Oelke et al., 1992; Kurt et al., 2011).

Studies have shown that safflower seed supplementation can have positive effects on fatty acid profiles in meat of lambs, cattle and broiler (Bolte et al., 2002; Shafey et al., 2003; Boles et al., 2005; Peng et al., 2010) and also egg (Shafey et al., 2003; Hur et al., 2003; Malakian et al., 2011) and cow milk (Stegeman et al., 1992). However, the level of cholesterol in the egg has not been affected (Hur et al., 2003; Malakian et al., 2011).

This research was carried out to determine the effects of GSS on fatty acids composition and cholesterol level of chicken meat.

\section{Material and Methods}

In total, 120, 1-old broiler chicks were divided into four groups $(0,2.5 \%, 5 \%$ and $10 \%$ were added to commercial broiler diet) of 30 chicks each one was three replicate with similar body weights $(41.8 \pm 0.4 \mathrm{~g})$. They were kept in floor pens

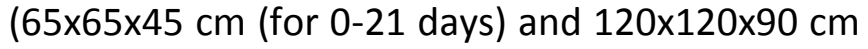
(for 22-41 days) in a chicken chamber.

Treatment birds were fed on the basal (commercial) diets supplemented with 0 (control) (0), 25 (2.5\%), 50 (5\%) and 100 (10\%) g GSS per kg diet. Nutrient compositions of the commercial diets are shown in Table 1. Fatty acid composition and cholesterol content of the safflower seed oil was determined by gas chromatography (Table 2).

Chickens were fed ad libitum during study. In experimental poultry house, continuous $24 \mathrm{~h}$ day light and $19-34{ }^{\circ} \mathrm{C}$ ambient temperature (decrease from $34{ }^{\circ} \mathrm{C}$ day old age to $19{ }^{\circ} \mathrm{C}$ gradually) was obtained for 41 days.

Table 1. Ingredients and chemical composition of the commercial diets

Çizelge 1. Ticari yemlerin bileşenleri ve kimyasal kompozisyonu

\begin{tabular}{|c|c|c|}
\hline $\begin{array}{l}\text { Ingredient (\%, } \\
\mathrm{w} / \mathrm{w}) \\
\text { Bileşen }(\%, w / w)\end{array}$ & $\begin{array}{l}\text { Starter feed ( } 1^{\text {st }} \text { - } \\
15^{\text {th }} \text { days) } \\
\text { Başlangıç yemi } \\
\text { (1.-15. günler) }\end{array}$ & $\begin{array}{l}\text { Grower feed (16 }{ }^{\text {th }}- \\
41^{\text {st }} \text { days) } \\
\text { Büyütme yemi (16.- } \\
41 . \text { Günler) }\end{array}$ \\
\hline Maize & 52 & 47 \\
\hline Soybean meal & - & 8 \\
\hline Low-fat soya & 13 & - \\
\hline Full-fat soya & 20 & 32 \\
\hline Corn gluten & 5 & 4 \\
\hline Boncalite & - & 3 \\
\hline Fish meal & 5.2 & 2 \\
\hline DCP & 3 & 2 \\
\hline Limestone & 0.5 & 0.6 \\
\hline Methionine & 0.2 & 0.3 \\
\hline Lysine & 0.1 & 0.3 \\
\hline Threonine & 0.3 & 0.2 \\
\hline $\begin{array}{l}\text { Mineral \& Vitamin } \\
\text { Premix* }\end{array}$ & 0.3 & 0.3 \\
\hline Salt & 0.4 & 0.3 \\
\hline
\end{tabular}

Calculated composition

Hesaplanan bileşim

\begin{tabular}{lcc}
\hline ME $\left(\mathrm{kcal} \mathrm{kg}^{-1}\right)$ & 3200 & 3150 \\
$\begin{array}{l}\text { Crude protein, \% } \\
\text { (w/w) }\end{array}$ & 23 & 22 \\
$\begin{array}{l}\text { Lysine, \% (w/w) } \\
\text { Methionine + }\end{array}$ & 1.1 & 1.4 \\
cystein, \% (w/w) & 0.9 & 1.1 \\
Ca, \% (w/w) & 1.0 & 1.0 \\
P (available), \% & 0.45 & 0.5 \\
(w/w) &
\end{tabular}

*Per kg diet included 8000 IU Vitamin A, 800 IU Vitamin $D_{3}$, $15 \mathrm{mg}$ Vitamin $\mathrm{E}, 2 \mathrm{mg}$ Vitamin $\mathrm{K}_{3}, 4 \mathrm{mg}$ Vitamin $\mathrm{B}_{2}, 10 \mathrm{mg}$ Vitamin $\mathrm{B}_{12}, 80 \mathrm{mg} \mathrm{Mn}, 60 \mathrm{mg} \mathrm{Zn}, 25 \mathrm{mg} \mathrm{Fe}, 15 \mathrm{mg} \mathrm{Cu}, 0.25$ $\mathrm{mg} \mathrm{Co}, 1 \mathrm{~g}$ lodine, $0.2 \mathrm{mg}$ Se

*Yem, kilogram başına 8000 IU Vitamin A, 800 IU Vitamin $D_{3}, 15 \mathrm{mg}$ Vitamin $E, 2 \mathrm{mg}$ Vitamin $K_{3}, 4 \mathrm{mg}$ Vitamin $B_{2}, 10$ $\mathrm{mg}$ Vitamin $B_{12}, 80 \mathrm{mg} \mathrm{Mn}, 60 \mathrm{mg} \mathrm{Zn,} 25 \mathrm{mg} \mathrm{Fe}, 15 \mathrm{mg} \mathrm{Cu}$, $0.25 \mathrm{mg}$ Co, $1 \mathrm{~g}$ lodine, $0.2 \mathrm{mg}$ Se içerir.

One male and one female bird from each replicates of groups were randomly selected for slaughter. 6 birds for each group and 24 birds in 
total were slaughtered at 41 days. Following chilling of the carcass in coldwater, skin, thigh, breast and wings were dissected and collected. The samples were frozen and stored at $-20{ }^{\circ} \mathrm{C}$ until they were analyzed. Total lipids from tissues and feeds were extracted by standard procedures following homogenization in a suitable excess of chloroform/methanol (2:1) as described by Folch and Stanley, 1957.

Analyses of fatty acid composition were performed on FocusGC gas chromatograph (Thermo, Milan, Italy) equipped with the flame ionization detector and a capillary column (DBwax, $30 \mathrm{~m} \times 0.25 \mathrm{~mm}, 0.25 \mu \mathrm{m}$ film thickness; Agilent Technologies, Palo Alto, CA).

Table 2. Chemical composition of safflower seed oil Çizelge 2. Aspir tohumu yağının kimyasal bileşimi

\begin{tabular}{|c|c|}
\hline $\begin{array}{l}\text { Fatty acids } \\
\text { Yağ asitleri }\end{array}$ & $\%(w / w)$ \\
\hline C 14:0 & 0.083 \\
\hline C 15:0 & 0.017 \\
\hline C 16:0 & 5.851 \\
\hline C $16: 1 \omega 7$ & 0.081 \\
\hline C 17:0 & 0.032 \\
\hline C $17: 1 \omega 8$ & 0.033 \\
\hline C 18:0 & 2.147 \\
\hline C $18: 1$ c9 & 27.690 \\
\hline C 18:2w6 & 63.101 \\
\hline C 18:3w3 & 0.090 \\
\hline C 20:0 & 0.396 \\
\hline C $20: 1 \omega 9$ & 0.212 \\
\hline C 20:2w6 & 0.024 \\
\hline 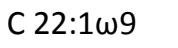 & 0.221 \\
\hline$\Sigma \mathrm{SFA}$ & 8.526 \\
\hline$\sum$ MUFA & 28.237 \\
\hline$\Sigma$ PUFA & 63.240 \\
\hline
\end{tabular}

Cholesterol (mg $100 \mathrm{~g}^{-1}$ )

Not detected Kolesterol (mg $\left.100 \mathrm{~g}^{-1}\right)$ Tespit edilmedi

GC conditions were performed according to TS EN ISO 5508 (Anonymous, 1996). The injector and detector ports were set at 250 and $280{ }^{\circ} \mathrm{C}$, respectively. The oven temperature program was initially set at $90{ }^{\circ} \mathrm{C}$ for $2 \mathrm{~min}$, and then increased at a rate of $10{ }^{\circ} \mathrm{C} \mathrm{min}^{-1}$ to $200{ }^{\circ} \mathrm{C}$, and then increased at a rate of $3{ }^{\circ} \mathrm{C} \mathrm{min}{ }^{-1}$ to $230{ }^{\circ} \mathrm{C}$, where it remained for the last $12 \mathrm{~min}$. The hydrogen carrier gas flow was set at $65 \mathrm{kPa}$, hydrogenate

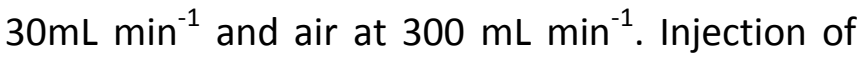
the $1 \mu \mathrm{L}$ samples was performed with a split ratio of $50: 1$.

Fatty acid methylation procedure according to the TS EN ISO 12966-2 method was performed (Anonymous, 2011). Approximately $100 \mathrm{mg}$ of sample weighed in a $10 \mathrm{ml}$ capped test tube, $2 \mathrm{ml}$ of isooctane and $0,1 \mathrm{ml}$ of $0,2 \mathrm{M} \mathrm{KOH}$ in methanol was added. Closure of the test tube is vortexed for 1 minute was stirred. Into the tube by adding $2 \mathrm{ml}$ of $40 \% \mathrm{NaCl}$ solution was shaken again. Isooctane phase was transferred to a vial by adding approximately $1 \mathrm{~g}$ of sodium hydrogen sulfate were added. About $30 \mathrm{~min}$. after aging for up to GC was taken from the supernatant was injected.

The same equipment was used for the cholesterol levels, except that the column (Model HP Ultra 2) was different.

Sample preparation, saponification and GC analysis of cholesterol were carried out according to the (Madzlan, 2008)

Differences between groups were analyzed with one-way analysis of variance (ANOVA) by using the statistical package SPSS (2001) for Windows version 11,0 . Significant means were subjected to multiple comparison test (Duncan) at alpha $=0.01$ level.

\section{Results and Discussion}

Effect of feeding with GSS on fatty acids composition of chicken meat

As the amount of safflower seed added in mixed feed had increased, the ratio of palmitic acid from among the major fatty acids had decreased in leg meat, skin and wing meat, and it had not changed in breast meat. Addition of safflower seed to the stearic acid amount in these parts had not had a significant effect. Again, while oleic acid, from among MUFA, had significantly decreased, the amount of linoleic acid, from among PUFA, had significantly increased in all parts.

The SFA amount of leg meat and breast meat 
had not changed by feeding with safflower seed added feed. But the SFA amount of skin and wing meat had decreased. While the total MUFA values had decreased in all the parts, the total PUFA values had significantly increased (Table 3, 4, 5 and 6).

Öztürk, (2004) had determined by his study that the rapeseed oil decreases the linoleic acid, increases the linolenic acid amount in leg and breast meat. Moreover, while MUFA amount had increased, the SFA amount had decreased. In the study of (Ciftci et al., 2010)), SFA had decreased and PUFA had increased in the leg of broiler chicken meats fed by antibiotics and cinnamon oil added feed. In this respect, our study is showing similarity with that study. While MUFA had decreased in our study, it had not been affected in that study. In the study of the same researcher, no change had been observed in the fatty acid composition of breast.

\section{Effect of feeding with GSS on cholesterol amount of chicken meat}

Feeding with safflower seed added feed had significantly affected the cholesterol level of chicken meat. In the group for which $10 \%$ safflower seed was added, the cholesterol amount had significantly decreased in leg, breast and skin parts compared to the control group $(P<0.05)$. And no significant change had been observed in the wing (Table 3, 4, 5 and 6).

In the study of (Rezaei and Monfaredi, 2010), which had been performed by adding $2 \%$ and $4 \%$ soybean oil and by adding suet at the same ratio to the ration, the cholesterol amount had decreased both in breast and leg meat of soybean oil added groups, and it had increased in groups for which suet had been added. The cholesterol amount, which had been $125.75 \mathrm{mg} 100 \mathrm{~g}^{-1}$ and

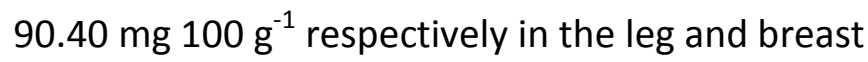
meat of the control group, had regressed to the level of $97.60 \mathrm{mg} 100 \mathrm{~g}^{-1}$ and $69.80 \mathrm{mg} 100 \mathrm{~g}^{-1}$ respectively in the leg and breast meat of group for which $2 \%$ soybean had been added. And in the group for which $4 \%$ suet had been added, it had increased to the level of $147.88 \mathrm{mg} 100 \mathrm{~g}^{-1}$ in leg meat, and $110.68 \mathrm{mg} 100 \mathrm{~g}^{-1}$ in breast meat. It is being observed that the cholesterol values of leg and breast meat are higher than the values in our study.

In the study performed by (Ciftci et al., 2010) by using cinnamon oil, the decrease of cholesterol values in leg and breast meat is showing similarity with our study. In the study of (Wang at al., 2006), that had been performed by adding different ratios of red fermented rice to the ration, the decrease of cholesterol amount in leg and breast meat is showing similarity with the values found in our study.

Dinh et al., (2011) had reported that the cholesterol amount had been determined in between 27-90 mg $100 \mathrm{~g}^{-1}$ in raw chicken meat and in between 59-154 mg $100 \mathrm{~g}^{-1}$ in cooked chicken meat. In their another study, they had

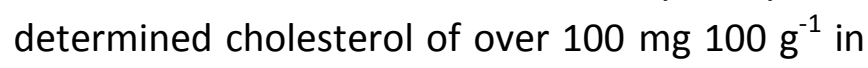
skin.

Bolte et al., (2002) had determined the cholesterol amount in leg meat as $59.3 \mathrm{mg} 100 \mathrm{~g}^{-1}$. This value is similar to the value determined in our study. 
Table 3. Effect of safflower seed on fatty acids content and cholesterol levels of legs meat of broiler chickens Çizelge 3. Etlik piliçlerin but eti yağ asitleri içeriği ve kolesterol düzeylerine aspir tohumunun etkisi

\begin{tabular}{|c|c|c|c|c|}
\hline & $\begin{array}{l}\text { Control } \\
(n=6) \\
\text { ort } \pm \text { S.S. }\end{array}$ & $\begin{array}{c}\% 2.5 \text { SS } \\
(n=6) \\
\text { ort } \pm \text { S.S. }\end{array}$ & $\begin{array}{c}\text { \%5 SS } \\
(n=6) \\
\text { ort } \pm \text { S.S. }\end{array}$ & $\begin{array}{c}\% 10 \text { SS } \\
(n=6) \\
\text { ort } \pm \text { S.S. }\end{array}$ \\
\hline \multicolumn{5}{|l|}{$\begin{array}{l}\text { Fatty acids, \% (w/w) } \\
\text { Yağ asitleri, \% (w/w) }\end{array}$} \\
\hline C $10: 0^{*}$ & $0.010 \pm 0.006^{a}$ & $0.015 \pm 0.009^{a}$ & $0.012 \pm 0.003^{a}$ & $0.016 \pm 0.003^{a}$ \\
\hline C 12:0 & $0.023 \pm 0.003^{a}$ & $0.020 \pm 0.002^{a}$ & $0.021 \pm 0.002^{a}$ & $0.023 \pm 0.002^{a}$ \\
\hline C $14: 0$ & $0.536 \pm 0.031^{a}$ & $0.526 \pm 0.039^{a}$ & $0.513 \pm 0.020^{\mathrm{ab}}$ & $0.482 \pm 0.055^{b}$ \\
\hline C 15:0 & $0.121 \pm 0.012^{a}$ & $0.125 \pm 0.006^{a}$ & $0.129 \pm 0.010^{a}$ & $0.124 \pm 0.011^{a}$ \\
\hline C 16:0 & $19.266 \pm 0.585^{\mathrm{a}}$ & $18.480 \pm 1.852^{\mathrm{ab}}$ & $17.668 \pm 0.653^{b c}$ & $17.216 \pm 0.967^{c}$ \\
\hline C 17:0 & $0.241 \pm 0.016^{b}$ & $0.264 \pm 0.028^{\mathrm{ab}}$ & $0.286 \pm 0.029^{a}$ & $0.250 \pm 0.015^{b}$ \\
\hline C 18:0 & $6.895 \pm 0.485^{\mathrm{a}}$ & $7.418 \pm 1.005^{\mathrm{a}}$ & $7.228 \pm 0.703^{a}$ & $7.950 \pm 1.549^{\mathrm{a}}$ \\
\hline C $20: 0$ & $0.078 \pm 0.004^{b}$ & $0.087 \pm 0.010^{\mathrm{ab}}$ & $0.100 \pm 0.016^{a}$ & $0.093 \pm 0.013^{\mathrm{ab}}$ \\
\hline$\sum$ SFA & $27.170 \pm 0.988^{\mathrm{a}}$ & $26.935 \pm 2.163^{\mathrm{a}}$ & $25.957 \pm 1.148^{\mathrm{a}}$ & $26.154 \pm 1.581^{\mathrm{a}}$ \\
\hline C $14: 1 \omega 5$ & $0.113 \pm 0.007^{\mathrm{a}}$ & $0.110 \pm 0.019^{a}$ & $0.086 \pm 0.014^{b}$ & $0.087 \pm 0.011^{b}$ \\
\hline C $16: 1 \omega 7$ & $3.238 \pm 0.216^{\mathrm{a}}$ & $2.715 \pm 0.514^{b}$ & $2.215 \pm 0.346^{c}$ & $2.257 \pm 0.231^{c}$ \\
\hline C $17: 1 \omega 8$ & $0.192 \pm 0.034^{a}$ & $0.178 \pm 0.025^{a}$ & $0.190 \pm 0.018^{a}$ & $0.165 \pm 0.022^{a}$ \\
\hline C 18:1 c9 & $32.682 \pm 1.140^{\mathrm{a}}$ & $31.006 \pm 1.817^{b}$ & $29.600 \pm 1.625^{b}$ & $27.619 \pm 2.177^{c}$ \\
\hline C 20:1w9 & $0.261 \pm 0.025^{a}$ & $0.241 \pm 0.023^{a}$ & $0.258 \pm 0.042^{a}$ & $0.205 \pm 0.048^{b}$ \\
\hline C 22:1w9 & $0.013 \pm 0.005^{a}$ & $0.014 \pm 0.002^{a}$ & $0.010 \pm 0.002^{a}$ & $0.010 \pm 0.002^{a}$ \\
\hline$\sum$ MUFA & $36.499 \pm 1.236^{\mathrm{a}}$ & $34.264 \pm 2.212^{b}$ & $32.359 \pm 1.883^{b c}$ & $30.343 \pm 2.397^{c}$ \\
\hline C 18:2w6 & $30.664 \pm 1.530^{c}$ & $33.560 \pm 1.866^{\mathrm{b}}$ & $36.361 \pm 0.919^{a}$ & $36.762 \pm 1.377^{\mathrm{a}}$ \\
\hline C $18: 3 \omega 3$ & $2.923 \pm 0.256^{\mathrm{a}}$ & $2.844 \pm 0.133^{a}$ & $2.758 \pm 0.176^{a}$ & $2.436 \pm 0.296^{b}$ \\
\hline C 18:3w6 & $0.199 \pm 0.030^{\mathrm{ab}}$ & $0.238 \pm 0.041^{\mathrm{ab}}$ & $0.280 \pm 0.087^{a}$ & $0.154 \pm 0.102^{b}$ \\
\hline C 20:2w6 & $0.244 \pm 0.043^{b}$ & $0.238 \pm 0.043^{b}$ & $0.277 \pm 0.018^{\mathrm{ab}}$ & $0.319 \pm 0.068^{a}$ \\
\hline C 20:3w3 & $1.503 \pm 0.475^{b}$ & $1.216 \pm 0.524^{b}$ & $1.279 \pm 0.337^{b}$ & $2.920 \pm 1.729^{a}$ \\
\hline C 20:4w6 & $0.025 \pm 0.004^{a}$ & $0.028 \pm 0.009^{a}$ & $0.022 \pm 0.005^{a}$ & $0.020 \pm 0.005^{a}$ \\
\hline C 20:5w3 & $0.052 \pm 0.010^{a}$ & $0.040 \pm 0.010^{b}$ & $0.026 \pm 0.002^{c}$ & $0.032 \pm 0.005^{c}$ \\
\hline C 22:6w3 & $0.194 \pm 0.079^{\mathrm{a}}$ & $0.168 \pm 0.112^{\mathrm{a}}$ & $0.171 \pm 0.043^{\mathrm{a}}$ & $0.309 \pm 0.170^{a}$ \\
\hline$\sum$ PUFA & $35.804 \pm 1.467^{c}$ & $38.332 \pm 2.426^{b}$ & $41.174 \pm 1.090^{\mathrm{a}}$ & $42.952 \pm 0.746^{\mathrm{a}}$ \\
\hline $\begin{array}{l}\left.\text { Cholesterol (mg } 100 \mathrm{~g}^{-1}\right) \\
\text { Kolesterol }\left(\mathrm{mg} 100 \mathrm{~g}^{-1}\right) \\
\end{array}$ & $62.38 \pm 5.39^{b}$ & $68.26 \pm 1.05^{a}$ & $61.40 \pm 4.70^{b}$ & $53.58 \pm 5.60^{c}$ \\
\hline
\end{tabular}


Table 4. Effect of safflower seed on fatty acid content and cholesterol levels of breast meat of broiler chickens Çizelge 4. Etlik piliçlerin göğüs eti yağ asitleri içeriği ve kolesterol düzeylerine aspir tohumunun etkisi

\begin{tabular}{|c|c|c|c|c|}
\hline & $\begin{array}{l}\text { Control } \\
(n=6) \\
\text { ort } \pm \text { S.S. }\end{array}$ & $\begin{array}{c}\begin{array}{c}\% 2.5 \text { SS } \\
(n=6)\end{array} \\
\text { ort } \pm \text { S.S. }\end{array}$ & $\begin{array}{c}\begin{array}{c}\% \text { SS } \\
(n=6)\end{array} \\
\text { ort } \pm \text { S.S. }\end{array}$ & $\begin{array}{c}\% 10 \text { SS } \\
(n=6) \\
\text { ort } \pm \text { S.S. }\end{array}$ \\
\hline \multicolumn{5}{|l|}{$\begin{array}{l}\text { Fatty acids, \% (w/w) } \\
\text { Yağ asitleri, \% (w/w) }\end{array}$} \\
\hline C $10: 0^{*}$ & $0.040 \pm 0.014^{b}$ & $0.052 \pm 0.014^{\mathrm{ab}}$ & $0.065 \pm 0.032^{\mathrm{a}}$ & $0.086 \pm 0.020^{a}$ \\
\hline C $12: 0$ & $0.036 \pm 0.008^{a}$ & $0.047 \pm 0.038^{\mathrm{a}}$ & $0.020 \pm 0.004^{b}$ & $0.031 \pm 0.011^{\mathrm{a}}$ \\
\hline C $14: 0$ & $0.521 \pm 0.021^{\mathrm{a}}$ & $0.478 \pm 0.055^{\mathrm{ab}}$ & $0.492 \pm 0.030^{\mathrm{ab}}$ & $0.452 \pm 0.059^{b}$ \\
\hline C $15: 0$ & $0.125 \pm 0.013^{\mathrm{a}}$ & $0.117 \pm 0.019^{\mathrm{a}}$ & $0.133 \pm 0.009^{a}$ & $0.128 \pm 0.009^{a}$ \\
\hline C $16: 0$ & $20.421 \pm 1.005^{\mathrm{a}}$ & $20.234 \pm 1.335^{\mathrm{a}}$ & $20.783 \pm 1.054^{\mathrm{a}}$ & $19.837 \pm 1.689^{\mathrm{a}}$ \\
\hline C 17:0 & $0.261 \pm 0.028^{a}$ & $0.290 \pm 0.067^{\mathrm{a}}$ & $0.308 \pm 0.044^{a}$ & $0.272 \pm 0.053^{\mathrm{a}}$ \\
\hline C $18: 0$ & $8.373 \pm 0.857^{\mathrm{a}}$ & $9.534 \pm 1.530^{\mathrm{a}}$ & $9.819 \pm 1.325^{\mathrm{a}}$ & $9.679 \pm 1.312^{\mathrm{a}}$ \\
\hline C $20: 0$ & $0.079 \pm 0.004^{b}$ & $0.093 \pm 0.033^{\mathrm{ab}}$ & $0.133 \pm 0.054^{\mathrm{a}}$ & $0.072 \pm 0.012^{b}$ \\
\hline$\sum$ SFA & $29.856 \pm 1.783^{a}$ & $30.845 \pm 2.800^{\mathrm{a}}$ & $31.753 \pm 1.963^{\mathrm{a}}$ & $30.557 \pm 2.769^{a}$ \\
\hline C $14: 1 \omega 5$ & $0.082 \pm 0.003^{a}$ & $0.071 \pm 0.015^{\mathrm{a}}$ & $0.055 \pm 0.010^{b}$ & $0.055 \pm 0.008^{b}$ \\
\hline C $16: 1 \omega 7$ & $2.519 \pm 0.155^{\mathrm{a}}$ & $2.153 \pm 0.486^{\mathrm{ab}}$ & $1.768 \pm 0.333^{b c}$ & $1.599 \pm 0.302^{c}$ \\
\hline C $17: 1 \omega 8$ & $0.142 \pm 0.030^{a}$ & $0.129 \pm 0.013^{a}$ & $0.115 \pm 0.014^{a}$ & $0.076 \pm 0.0013^{b}$ \\
\hline C $18: 1$ c9 & $30.559 \pm 1.447^{\mathrm{a}}$ & $27.902 \pm 1.519^{b}$ & $27.623 \pm 1.620^{b c}$ & $25.488 \pm 2.014^{c}$ \\
\hline C $20: 1 \omega 9$ & $0.216 \pm 0.033^{a}$ & $0.171 \pm 0.016^{a}$ & $0.176 \pm 0.064^{a}$ & $0.195 \pm 0.114^{a}$ \\
\hline C 22:1w9 & $0.014 \pm 0.010^{b}$ & $0.016 \pm 0.008^{b}$ & $0.030 \pm 0.010^{a}$ & $0.019 \pm 0.003^{b}$ \\
\hline$\sum$ MUFA & $33.532 \pm 1.587^{\mathrm{a}}$ & $30.442 \pm 2.042^{b}$ & $29.767 \pm 1.904^{b c}$ & $27.432 \pm 2.219^{c}$ \\
\hline C $18: 2 \omega 6$ & $29.522 \pm 2.018^{b}$ & $31.331 \pm 2.417^{\mathrm{ab}}$ & $30.940 \pm 2.307^{\mathrm{ab}}$ & $32.513 \pm 1.771^{a}$ \\
\hline C $18: 3 \omega 3$ & $2.666 \pm 0.352^{\mathrm{a}}$ & $2.398 \pm 0.390^{\mathrm{ab}}$ & $1.994 \pm 0.322^{b}$ & $1.776 \pm 0.345^{b}$ \\
\hline C $18: 3 \omega 6$ & $0.184 \pm 0.030^{\mathrm{a}}$ & $0.213 \pm 0.032^{\mathrm{a}}$ & $0.174 \pm 0.026^{\mathrm{a}}$ & $0.162 \pm 0.042^{\mathrm{a}}$ \\
\hline C $20: 2 \omega 6$ & $0.344 \pm 0.059^{b}$ & $0.391 \pm 0.078^{b}$ & $0.488 \pm 0.138^{\mathrm{ab}}$ & $0.590 \pm 0.141^{a}$ \\
\hline C $20: 3 \omega 3$ & $3.037 \pm 1.314^{b}$ & $3.485 \pm 1.397^{\mathrm{ab}}$ & $3.807 \pm 1.033^{\mathrm{ab}}$ & $5.937 \pm 1.994^{a}$ \\
\hline C $20: 4 \omega 6$ & $0.046 \pm 0.010^{b}$ & $0.045 \pm 0.019^{b}$ & $0.044 \pm 0.005^{b}$ & $0.061 \pm 0.013^{a}$ \\
\hline C $20: 5 \omega 3$ & $0.107 \pm 0.049^{a}$ & $0.089 \pm 0.056^{a}$ & $0.079 \pm 0.036^{a}$ & $0.101 \pm 0.034^{a}$ \\
\hline C 22:6w3 & $0.457 \pm 0.251^{\mathrm{ab}}$ & $0.505 \pm 0.143^{b}$ & $0.725 \pm 0.307^{\mathrm{a}}$ & $0.630 \pm 0.161^{\mathrm{ab}}$ \\
\hline$\sum$ PUFA & $36.363 \pm 1.551^{c}$ & $38.457 \pm 1.351^{b}$ & $38.251 \pm 1.599^{b}$ & $41.77 \pm 0.951^{a}$ \\
\hline 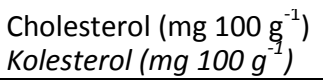 & $63.22 \pm 4.10^{\mathrm{a}}$ & $65.52 \pm 4.56^{\mathrm{a}}$ & $61.82 \pm 6.35^{\mathrm{a}}$ & $53.68 \pm 4.65^{b}$ \\
\hline
\end{tabular}

*: Means in the same row with different superscript letters are significantly different $(\mathrm{P}<0.01)$.

*: Aynı satırda farklı harfle gösterilen değerler birbirinden farklıdır $(P<0.01)$ 
Table 5. Effect of safflower seed on fatty acid content and cholesterol levels of skin of broiler chickens Çizelge 5. Etlik piliçlerin deri yağ asitleri içeriği ve kolesterol düzeylerine aspir tohumunun etkisi

\begin{tabular}{|c|c|c|c|c|}
\hline & $\begin{array}{l}\text { Control } \\
(n=6) \\
\text { ort } \pm \text { S.S. }\end{array}$ & $\begin{array}{c}\% 2.5 \text { SS } \\
(n=6) \\
\text { ort } \pm \text { S.S. }\end{array}$ & $\begin{array}{c}\% 5 \text { SS } \\
(n=6) \\
\text { ort } \pm \text { S.S. }\end{array}$ & $\begin{array}{c}\% 10 \text { SS } \\
(n=6) \\
\text { ort } \pm \text { S.S. }\end{array}$ \\
\hline \multicolumn{5}{|l|}{ Fatty acids, $\%(w / w)$} \\
\hline \multicolumn{5}{|l|}{ Yağ asitleri, \% (w/w) } \\
\hline C $10: 0^{*}$ & $0.009 \pm 0.003^{\mathrm{a}}$ & $0.007 \pm 0.001^{a}$ & $0.009 \pm 0.002^{\mathrm{a}}$ & $0.007 \pm 0.001^{a}$ \\
\hline C 12:0 & $0.025 \pm 0.003^{a}$ & $0.023 \pm 0.001^{a}$ & $0.021 \pm 0.005^{a}$ & $0.020 \pm 0.006^{a}$ \\
\hline C 14:0 & $0.563 \pm 0.033^{a}$ & $0.550 \pm 0.033^{a b}$ & $0.537 \pm 0.020^{b c}$ & $0.522 \pm 0.018^{c}$ \\
\hline C 15:0 & $0.122 \pm 0.011^{\mathrm{a}}$ & $0.130 \pm 0.006^{\mathrm{a}}$ & $0.128 \pm 0.015^{\mathrm{a}}$ & $0.125 \pm 0.009^{a}$ \\
\hline C 16:0 & $18.847 \pm 0.508^{a}$ & $17.850 \pm 1.373^{b}$ & $17.228 \pm 0.824^{b}$ & $16.663 \pm 0.718^{b}$ \\
\hline C $17: 0$ & $0.245 \pm 0.021^{b}$ & $0.259 \pm 0.021^{\mathrm{ab}}$ & $0.278 \pm 0.015^{\mathrm{a}}$ & $0.240 \pm 0.006^{b}$ \\
\hline C $18: 0$ & $6.095 \pm 0.307^{a}$ & $6.264 \pm 0.255^{a}$ & $6.362 \pm 0.664^{a}$ & $5.986 \pm 0.315^{a}$ \\
\hline C $20: 0$ & $0.083 \pm 0.005^{b}$ & $0.088 \pm 0.006^{b}$ & $0.204 \pm 0.019^{\mathrm{a}}$ & $0.092 \pm 0.007 b$ \\
\hline$\sum$ SFA & $25.989 \pm 0.798^{\mathrm{a}}$ & $25.171 \pm 1.514^{a b}$ & $24.767 \pm 1.159^{b}$ & $23.660 \pm 0.977^{b}$ \\
\hline C $14: 1 \omega 5$ & $0.125 \pm 0.006^{a}$ & $0.110 \pm 0.012^{\mathrm{ab}}$ & $0.106 \pm 0.019^{\mathrm{ab}}$ & $0.097 \pm 0.010^{b}$ \\
\hline$C 16: 1 \omega 7$ & $3.320 \pm 0.393^{a}$ & $2.95 \pm 0.422^{\mathrm{ab}}$ & $2.487 \pm 0.500^{b}$ & $2.438 \pm 0.187^{b}$ \\
\hline C $17: 1 \omega 8$ & $0.223 \pm 0.014^{a}$ & $0.224 \pm 0.010^{a}$ & $0.194 \pm 0.030^{b}$ & $0.186 \pm 0.030^{b}$ \\
\hline C $18: 1$ c9 & $34.992 \pm 1.028^{\mathrm{a}}$ & $32.175 \pm 1.079^{b}$ & $31.102 \pm 2.059^{b c}$ & $30.120 \pm 0.622^{c}$ \\
\hline 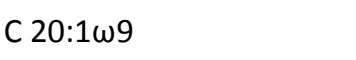 & $0.258 \pm 0.022^{a}$ & $0.223 \pm 0.016^{b}$ & $0.213 \pm 0.031^{b}$ & $0.214 \pm 0.007^{b}$ \\
\hline C 22:1w9 & $0.010 \pm 0.002^{\mathrm{a}}$ & $0.011 \pm 0.004^{\mathrm{a}}$ & $0.008 \pm 0.002^{\mathrm{a}}$ & $0.009 \pm 0.001^{\mathrm{a}}$ \\
\hline$\sum$ MUFA & $38.928 \pm 1.260^{a}$ & $35.693 \pm 1.435^{\mathrm{b}}$ & $34.110 \pm 2.555^{c}$ & $33.064 \pm 0.684^{c}$ \\
\hline C 18:2w6 & $31.067 \pm 1.399^{c}$ & $35.050 \pm 1.961^{b}$ & $37.105 \pm 1.679^{\mathrm{ab}}$ & $38.979 \pm 0.778^{a}$ \\
\hline C $18: 3 \omega 3$ & $3.184 \pm 0.173^{a}$ & $3.196 \pm 0.184^{a}$ & $3.052 \pm 0.129^{a}$ & $3.470 \pm 1.202^{a}$ \\
\hline C $18: 3 \omega 6$ & $0.198 \pm 0.035^{a}$ & $0.244 \pm 0.042^{a}$ & $0.252 \pm 0.058^{\mathrm{a}}$ & $0.150 \pm 0.124^{a}$ \\
\hline$C 20: 2 \omega 6$ & $0.171 \pm 0.013^{a}$ & $0.189 \pm 0.024^{a}$ & $0.162 \pm 0.070^{\mathrm{a}}$ & $0.190 \pm 0.012^{a}$ \\
\hline C $20: 3 \omega 3$ & $0.486 \pm 0.136^{b}$ & $0.177 \pm 0.102^{c}$ & $0.617 \pm 0.147^{a}$ & $0.672 \pm 0.157^{a}$ \\
\hline C 20:4w6 & $0.017 \pm 0.001^{a}$ & $0.017 \pm 0.003^{a}$ & $0.015 \pm 0.003^{a}$ & $0.016 \pm 0.005^{a}$ \\
\hline C 20:5w3 & $0.039 \pm 0.011^{a}$ & $0.028 \pm 0.011^{a}$ & $0.028 \pm 0.009^{a}$ & $0.027 \pm 0.005^{a}$ \\
\hline C 22:6w3 & $0.031 \pm 0.006^{\mathrm{a}}$ & $0.039 \pm 0.014^{a}$ & $0.072 \pm 0.033^{\mathrm{b}}$ & $0.065 \pm 0.012^{b}$ \\
\hline$\Sigma$ PUFA & $34.893 \pm 1.611^{\mathrm{c}}$ & $38.940 \pm 2.139^{b}$ & $41.303 \pm 1.619^{b}$ & $43.569 \pm 1.580^{a}$ \\
\hline $\begin{array}{l}\left.\text { Cholesterol (mg } 100 \mathrm{~g}^{-1}\right) \\
\left.\text { Kolesterol (mg } 100 \mathrm{~g}^{-1}\right)\end{array}$ & $134.56 \pm 12.72^{\mathrm{a}}$ & $138.99 \pm 10.90^{\mathrm{a}}$ & $125.46 \pm 8.12^{b}$ & $123.25 \pm 7.51^{b}$ \\
\hline
\end{tabular}

*: Means in the same row with different superscript letters are significantly different $(\mathrm{P}<0.01)$.

*: Aynı satırda farklı harfle gösterilen değerler birbirinden farklıdır $(P<0.01)$ 
Table 6. Effect of safflower seed on fatty acid content and cholesterol levels of wings meat of broiler chickens Çizelge 6. Etlik piliçlerin kanat eti yağ asitleri içeriği ve kolesterol düzeylerine aspir tohumunun etkisi

$\begin{array}{ccccc}\text { Control } & \% 2.5 \text { SS } & \% 5 \text { SS } & \% 10 \text { SS } \\ (n=6) & (n=6) & (n=6) & (n=6)\end{array}$

Fatty acids, \% (w/w)

Yağ asitleri, \% (w/w)

C 10:0*

C $12: 0$

C $14: 0$

C 15:0

C 16:0

C $17: 0$

C 18:0

C 20:0

$\Sigma$ SFA

C $14: 1 \omega 5$

C 16:1 $1 \omega 7$

C 17:1 $1 \omega 8$

C $18: 1 \mathrm{c} 9$

C 20:1 $\omega 9$

C 22:1 $\omega 9$

$\Sigma$ MUFA

C 18:2w6

C 18:3 $\omega 3$

C 18:3w6

C 20:2 $\omega 6$

C 20:3 $\omega 3$

C 20:4 $\omega 6$

C 20:5 $\omega 3$

C 22:6w3

$\Sigma$ PUFA

ort \pm S.S.

ort \pm S.S.

ort \pm S.S.

ort \pm S.S.

$\begin{array}{cc}0.017 \pm 0.009^{\mathrm{a}} & 0.016 \pm 0.005^{\mathrm{a}} \\ 0.022 \pm 0.002^{\mathrm{a}} & 0.025 \pm 0.011^{\mathrm{a}} \\ 0.536 \pm 0.024^{\mathrm{a}} & 0.521 \pm 0.031^{\mathrm{a}} \\ 0.123 \pm 0.010^{\mathrm{a}} & 0.126 \pm 0.009^{\mathrm{a}} \\ 19.437 \pm 0.470^{\mathrm{a}} & 18.420 \pm 1.280^{\mathrm{ab}} \\ 0.250 \pm 0.016^{\mathrm{b}} & 0.261 \pm 0.024^{\mathrm{b}} \\ 6.958 \pm 0.287^{\mathrm{b}} & 7.650 \pm 0.665^{\mathrm{a}} \\ 0.077 \pm 0.015^{\mathrm{b}} & 0.073 \pm 0.012^{\mathrm{b}} \\ 27.420 \pm 0.621^{\mathrm{a}} & 27.092 \pm 1.628^{\mathrm{a}}\end{array}$

$0.109 \pm 0.005^{a}$

$3.073 \pm 0.261^{a}$

$0.186 \pm 0.021^{a}$

$32.807 \pm 1.437^{\mathrm{a}}$

$0.244 \pm 0.035 a$

$0.011 \pm 0.002^{\mathrm{a}}$

$36.430 \pm 1.603^{\mathrm{a}}$

$30.610 \pm 1.128^{c}$

$2.942 \pm 0.143^{\mathrm{a}}$

$0.189 \pm 0.021^{a b}$

$0.260 \pm 0.036^{b}$

$1.555 \pm 0.342^{\mathrm{a}}$

$0.028 \pm 0.004^{\mathrm{a}}$

$0.064 \pm 0.015^{\mathrm{a}}$

$0.231 \pm 0.072^{\mathrm{a}}$

$35.879 \pm 1.469^{c}$
$0.090 \pm 0.012^{b}$

$2.719 \pm 0.393^{\mathrm{a}}$

$0.153 \pm 0.038^{\mathrm{a}}$

$30.064 \pm 1.489^{b}$

$0.180 \pm 0.029^{c}$

$0.012 \pm 0.002^{\mathrm{a}}$

$33.218 \pm 1.659^{b}$

$33.566 \pm 2.013^{b}$

$2.778 \pm 0.218^{\mathrm{ab}}$

$0.232 \pm 0.039^{\mathrm{a}}$

$2.119 \pm 0.813^{\mathrm{a}}$

$0.038 \pm 0.009^{\mathrm{a}}$

$0.068 \pm 0.019^{a}$

$0.307 \pm 0.127^{\mathrm{a}}$

$39.402 \pm 1.814^{\mathrm{b}}$
$0.294 \pm 0.036^{\mathrm{ab}}$
$0.012 \pm 0.002^{b}$

$0.020 \pm 0.001^{a}$

$0.528 \pm 0.019^{a}$

$0.134 \pm 0.008^{a}$

$19.341 \pm 0.373^{a}$

$0.306 \pm 0.014^{\mathrm{a}}$

$7.943 \pm 0.428^{a}$

$0.121 \pm 0.025^{a}$

$28.405 \pm 0.544^{a}$

$0.083 \pm 0.013^{b}$

$2.321 \pm 0.339^{b}$

$0.183 \pm 0.058^{\mathrm{a}}$

$30.036 \pm 0.756^{b}$

$0.217 \pm 0.038^{\mathrm{ab}}$

$0.015 \pm 0.006^{\mathrm{a}}$

$32.855 \pm 1.041^{b}$

$33.291 \pm 1.771^{\mathrm{b}}$

$2.424 \pm 0.240^{c}$

$0.160 \pm 0.063^{b}$

$0.321 \pm 0.027 a$

$1.961 \pm 0.456^{a}$

$0.021 \pm 0.009^{\mathrm{a}}$

$0.034 \pm 0.009^{b}$

$0.317 \pm 0.115^{\mathrm{a}}$

$38.529 \pm 1.360^{b}$
$0.012 \pm 0.002^{b}$

$0.019 \pm 0.003^{\mathrm{a}}$

$0.408 \pm 0.180^{\mathrm{a}}$

$0.126 \pm 0.012^{\mathrm{a}}$

$17.403 \pm 0.774^{b}$

$0.260 \pm 0.024^{b}$

$6.844 \pm 0.494^{b}$

$0.082 \pm 0.013^{b}$

$25.154 \pm 1.141^{b}$

$0.081 \pm 0.007^{b}$

$2.332 \pm 0.147^{b}$

$0.160 \pm 0.023^{\mathrm{a}}$

$28.994 \pm 0.748^{b}$

$0.198 \pm 0.032^{\mathrm{bc}}$

$0.009 \pm 0.001^{\text {a }}$

$31.774 \pm 0.743^{b}$

$37.356 \pm 1.151^{\mathrm{a}}$

$2.626 \pm 0.153^{b c}$

$0.183 \pm 0.101^{a b}$

$0.294 \pm 0.044^{a}$

$2.057 \pm 0.710^{\mathrm{a}}$

$0.027 \pm 0.005^{\mathrm{a}}$

$0.046 \pm 0.016^{\mathrm{ab}}$

$0.290 \pm 0.080^{\mathrm{a}}$

$42.879 \pm 1.025^{a}$

Cholesterol (mg $100 \mathrm{~g}^{-1}$ ) Kolesterol (mg $100 \mathrm{~g}^{-1}$ )

$59.31 \pm 3.31^{\mathrm{a}}$

$62.03 \pm 3.46^{\mathrm{a}}$

$62.40 \pm 3.18^{a}$

$59.57 \pm 3.19^{a}$

*: Means in the same row with different superscript letters are significantly different $(\mathrm{P}<0.01)$.

*: Aynı satırda farklı harfle gösterilen değerler birbirinden farklıdır $(P<0.01)$

\section{Conclusions}

Safflower seed had significantly affected the fatty acid composition in the chicken meat. In the chicken meat which had been fed by mixed feed with $10 \%$ GSS addition, the PUFA amount had significantly increased, MUFA amount had significantly decreased. Also, cholesterol content significantly decrased in this group.

PUFA can help to reduce bad cholesterol levels in blood and this could reduce the risk of heart disease and stroke. PUFA also provide essential fats that body needs but can not produce itself (such as omega 3 and omega 6) in human body. In this study PUFA amount had been significantly increased in legs, breast, skin, and wings meat of broiler chicks by adding safflower seed.

As a conclusion, adding $10 \%$ grinded safflower seed to chicken diets could reduce cholesterol levels in meat and also had positive affects on some fatty acids levels. 


\section{References}

Anonymous, (1996). Hayvansal ve bitkisel katı ve sıvı yağlarYağ asitleri metil esterlerinin gaz kromatoğrafisiyle analizi. TSE yayınları, TS No: TS 4664 EN ISO 5508, Ankara.

Anonymous, (2011). Hayvansal ve bitkisel katı ve sıvı yağlaryağ asitleri metil esterlerinin gaz kromatoğrafisiBölüm 2: Yağ asitleri metil esterlerinin hazırlanması. TSE yayınları, TS No: 12966/2, Ankara.

Boles, J.A., Kott, R.W., Hatfield, P.G., Bergman, J.W. \& Flynn, C.R. (2005). Supplemental safflower oil affects the fatty acid profile, including conjugated linoleic acid, of lamb. Journal of Animal Science, 83,2175-2181.

Bolte, M.R., Hess, B.W., Means, W.J., Moss, G.E. \& Rule, D.C. (2002). Feeding lambs high-oleat or high-linoleat safflower seeds differentially influences carcass fatty acid composition. Journal of Animal Science, 80,609-616.

Çiftçi, M., Şimşek, Ü.G., Yüce, A., Yılmaz, Ö. \& Dalkılıç, B. (2010). Effects of dietary antibiotic and cinnamon oil supplementation on antioxidant enzyme activities, cholesterol levels and fatty acid compositions of serum and meat in broiler chickens. Acta Veterinaria, 79,33-40.

Dajue L. \& Mündel, H.H. (1996). Safflower, Gatersleben/International Plant Genetic Resources Institute, Rome, Italy (ISBN92- 9043-297-7).

Dinh, T.T.N., Thompson, L.D., Galyean, M.L., Brooks, J.C., Patterson, K.Y. \& Boylan., L.M. (2011). Cholesterol content and methods for cholesterol. Determination in meat and poultry. Comprehensive Reviews in Food Science Food Safety. 10,269-289.

Folch, J., Lees, M. \& Sloane-Stanley, G.H. (1957). A simple method for the isolation and purification of total lipids from animal tissues. Journal of Biological Chemistry, 226,497-509.

Hur, S.J., Kang, G.H., Jeong, J.Y., Yang, H.S., Ha, Y.L., Park, G.B. \& Joo, S.T. (2003). Effect of Dietary Conjugated Linoleic Acid on Lipid Characteristics of Egg Yolk. Asian-Australasian. Journal of Animal Science, 16(8),1165-1170.

Kurt, O., Uysal, H., Demir, A., Özgür, Ü. \& Kılınç, R. (2011). Samsun ekolojik koşullarına adapte olabilecek kışlık aspir (Carthamus tinctorius L.) genotiplerinin belirlenmesi üzerinde bir araştırma. Anadolu Tarım Bilimleri Dergisi, 26(3),212-216.
Madzlan, K. (2008). Determination of cholesterol in several types of eggs by gas chromatography. Journal of Tropical Agriculture and Food Science, 36,2.

Malakian, M., Hassanabadi, A. \& Heidariniya, A. (2011). Effects of safflower seed on performance, carcass traits and blood parameters of broilers. Research Journal of Poultry Sciences, 4(2),18-21.

Mündel H., Blackshaw, R.E., Byers, J.R., Huang, H.C., Johnson, D.L., Keon, R., Kubik, J., McKenzie, R., Otto, B., Roth, B. \& Stanford, K. (2004). Safflower Production on the Canadian Prairies: revisited in 2004 Agriculture and Agri-Food Canada, Lethbridge Research Centre, Lethbridge, Alberta.

Oelke, E.A., Oplinger, E.S., Teynor, T.M., Putnam, D.H., Doll, J.D., Kelling, K.A., Durgan, B.R. \& Noetzel D.M. (1992). Safflower. Alternative Field Crops Manual, University of Wisconsin, https://hort.purdue.edu/newcrop/afcm/safflower. html. Access date: May 2012.

Öztürk, E. (2004). Etlik piliç karma yemlerine farklı düzeylerde kolza yağı ve vitamin E katılmasının et kalitesi ve besi performansına etkisi (Doktora Tezi). Ankara Üniversitesi Fen Bilimleri Enstitüsü, Ankara.

Peng, Y.S., Brown, M.A., Wua, J.P. \& Liu, Z. (2010). Different oilseed supplements alter fatty acid composition of different adipose tissues of adult ewes. Meat Science, 85,542-549.

Rezaei, M. \& Monfaredi, A. (2010). Effects of supplemental fat to low metabolizable energy diets on cholesterol and triglyceride contents of broilers meat. American Journal of Animal and Veterinary Sciences, 5(2), 121-126.

Shafey, T.M., Dingle, J.G., McDonald, M.W. \& Kostner, K. (2003). Effect of type of grain and oil supplement on the performance, blood lipoproteins, egg cholesterol and fatty acids of laying hens. International Journal of Poultry Science, 2(3),200206.

SPSS, (2001). SPSS Version 11.0. SPSS Inc., Chicago, 151 Illinois, USA.

Stegeman, G.A., Baer, R.J., Schingoether, D.J. \& Casper, D.P. (1992). Composition and flavor of milk and butter from cows fed unsaturated dietary fat and receiving bovine somatotropin. Journal of Dairy Science, 75,962-970.

Wang, J.J., Pan, T.M., Shieh, M.J. \& Hsu, C.C. (2006). Effect of red mold rice supplements on serum and meat cholesterol levels of broilers chicken. Applied Microbiology and Biotechnology, 71,812-818. 